\title{
3
}

\section{RESHAPING NIGERIA'S AFRICAN POLICY IN A POST-APARTHEID ERA}

\author{
Olufemi Adelusi
}

\begin{abstract}
This paper attempts a critical analysis of Nigeria's African policy. It argues for a distinct policy blueprint on Africa which is recognized as a part of the country's foreign policy and not the foreign policy itself writ large. The paper emphasizes that "Africa as the centre piece of our foreign policy" is not the same thing as a proper Nigerian policy on Africa which in the main is the summary of all the West African, Central African, Southern African, Horn of African and the Magrhebin policies.
\end{abstract}

It is argued that reshaping Nigeria's African -policy essentially entails a conscious attempt on the part of the envisaged democratic institutions to formulate a coherent African policy with the component regional policies all of which could then be well monitored and evaluated periodically.

The paper concludes with suggestions on likely areas of emphasis for Nigeria's real African Policy in a post-Apartheid era. These include a reexamination and possible adoption of both the "Akinyemi Doctrine", the formulation of strategies for the upliftment of the dignity of the African man on the continent or in the disapora, by pursuing progressive policies of human and community rights as well as internally coordinated and self-sustaining economic development. 
Reshaping Nigeria's African Policy in a Post-Apartheid Era 33

\section{INTRODUCTION}

Before any serious discussion of the above topic could be undertaken, it is in order to examine critically its two important aspects, namely, Nigeria's African policy on the one hand, and the post-Apartheid era on the other. These clarifications would enable us to determine which areas of Nigeria's African policy, as it exists, are deserving of change. It would also locate the objective of the paper in the analysis of Nigeria's African policy and not Nigeria's policy towards South Africa.

This paper is divided into four sections. First, is the introduction; second, conceptual clarification on Nigeria's African policy and post-Apartheid era, third, an examination of suggested main areas of emphasis in an envisaged Nigeria's African policy blue print in a post-Apartheid era; and fourth, the conclusion.

\section{II}

\section{CONCEPTUAL CLARIFICATION ON NIGERIA'S FOREIGN POLICY IN A POST-APARTHEID ERA}

Nigeria's African Policy is expected to be composed of the main elements of her West African, Central African, Southern African and Maghrebin policies. It has been observed that what Nigeria calls its African policy is nothing other than a summary of her foreign policy which has Africa as its core. Furthermore, anti-Apartheid policy became the main thrust of what successive Nigerian governments have articulated as her African policy. There were blueprints for regional policies which all continued to be lumped together as the nation's foreign policy. This lapse has implications f:r the seriousness with which elements of such policies could be advanced, pursued or re-evaluated; thus, .the successes and, failures of most of the policy thrusts are difficult to grapple with, either for the purpose of a follow up or the evolution of options.

There have been scholarly attempts at categorizing Nigeria's foreign policy thrusts in Africa as the nation's African policy. Such efforts seem to have merely read the patterns of systemic adaptation or adjustment by Nigeria to her African environment. This view comes out of one of the many early declarations by those deciding and or implementing Nigeria's foreign affairs at the beginning of the post-independence era. Such declaration reaffirms the obvious when it states that "... Nigeria is an African nation, it is part and parcel of that continent of Africa and therefore it is so completely involved in anything that pertains to that continent that it cannot be neutral and must never be considered as a neutralist country..." (Michael Sinclair, 1983:56). 


\section{Annals of The Social Science Council of Nigeria, No. 6, January —December 1994}

A notable scholarly work referred to above is the policy-oriented study carried out by National Institute for Policy and Strategic Studies, entitled "Nigeria's African Policy in the Eighties" (Imobigbe et al, 1980). This study analyzes some aspects of the amorphous Nigerian African policy. If anything, it brings out sound elements which are necessary for some nascent regional policies that should make the desired African policy. Another equally important study on the search for African policy is that of Ogunbadejo: "General Gowon's African Policy" (Ogunbadejo, 1977: 36-50). In this study, he sees the Nigerian civil war as the catalyst and, thus, places the evolution of the West African policy and the entire African policy under General Gowon at the door step of the war.

Imobigbe describes the following as the main objectives of the then new foreign policy in which Africa has become the centre-piece (Imobighe, op cit):

First, the defence of our sovereignty, independence and territorial integrity. Second, the creation of the necessary political and economic conditions in Africa and the rest of the < world which will facilitate the defence of the independence and the territorial integrity of all African countries while at the same time fostering national self reliance and rapid economic development. Third, the promotion of equality and self reliance in Africa and the rest of the developing world. Fourth, the promotion and defence of justice and respect for human dignity, especially the dignity of the blackman. Fifth, the defence and promotion of world peace.

The above principles were contained in a broadcast to the Nation by the then Head of State, General Obasanjo, As if he was reacting to the confusion created by the mixedgrill, he emphasized that "these objectives are to be pursued with the realization that the centre-piece of our foreign policy is Africa" (Obasanjo, 1976: 49). This concern about where the emphasis should be in the Nigerian policy was well observed by Stephen Wright, when he opined that "there has been some contention about whether the focus should be egocentric, that is to say purely Nigerian, whether it should serve the West African region, Africa as a whole or its broadest, the interests of black people throughout the world" (Wright, 1981: 1685).

Ogunbadejo's article charts a different course by articulating the different strands of regional policy components of Gowon's African policy, He examines and illustrates Gowon's regional organizational policy component of Nigeria's African policy by classifying it as Nigeria's support for the O AU. and its charter as well as AfricanCaribbean and Pacific countries negotiation with EEC, on the one hand, and efforts towards 
ending racial discrimination in Southern Africa, on the other.

Furthermore, Nigeria's West African policy under Gowon was similarly linked to the catalyst which the civil war provided. In fact, the conflict was observed to have brought home to the federal leaders the practical importance of having friendly neighbours. The aggressive regional policy was three-pronged, viz: improving and strengthening Nigeria's relations with West African States, maintaining political stability in the region and providing leadership for the setting up of an all-embracing regional economic grouping (Ogunbadejo, op cit. 44-45). Another scholar observed the missing link in the country's Africa-centredness of her foreign policy, arguing that "there was little or no attempt to identify Nigeria's national interests in policy objectives in relation to African affairs" (Fafowora, 1980: 32). The above scholarly observations, though pertinent, are not exhaustive of the need to get a clear picture of the meaning of what really is Nigeria's African policy.

The institutional framework for evolving the "Africa as the centre-piece of our foreign policy" standpoint could be described as shaky. This explains in part the lack of a coherent African policy, both in conception or execution. Otherwise, how could it be explained that the Nigerian Institute of International Affairs, established just two years after independence, has remained modelled after the Royal Institute of International Affairs. Instead of its having research sub-units patterned along policies and immediate concerns of our foreign policy, we have less relevant subdivisions. Moreover, there is an absence of a constellation of experts on countries of West African, Central African, Southern African, Horn of Africa, and Maghreb in regions. It seems that there is no conscious in-house $\cdot$ policy of recruiting multilingual historians or social scientists in the Institute. This observable lapse, if not rectified, stands to undermine the nation's efforts at planning, formulating and understanding the various components of the nation's foreign policy, as well as the target audience of neb policy.

There are two cases which could illustrate some of the lapses gendered by lack of a coherent formulated African policy as defined above. The first case is that situation which brought Niger, a francophone member of ECOWAS, into collision with Nigeria, another member, over the African seat on the U.N. Security Council in September 197?4 It is true that the Republic of Niger was designated by the Organization of African Unity (Daniel Bach, 1985:7) to represent the African continent. Nevertheless, one imagines what a close collaborator of France, and economically weak, non-influential African state like Niger could be expected to contribute towards a strong stand against the forces which oppose sanctions or actively support the Apartheid system in South Africa, at the U.N. Security Council, during a period that the tempo for 
intensive campaign against racism and Apartheid system was high. The irony was that "a country like Niger, that is almost totally dependent on us for power, trade, imports and its life line..., cannot be made to bend to our will" (Oshuntokun, 1987:178)

Nigeria's initiative on that occasion might have looked disappointing to many other African states, and indeed it was, judging by the controversies that followed the action (Garba, 1978: 13). Through her spokesman, Joseph Garba, Nigeria suddenly discovered the old dictum of diplomacy: "Nigeria has only permanent interests." This dictum, we argue, should have been taken seriously when fashioning Nigeria's foreign policy and, in particular, those inevitable regional policies envisaged in a coherent African policy blueprint Nigeria's interests could have been made "...clear and practicable, not fatuous or sentimental or designed to soothe people's nerves or for propaganda purposes" (Sinclair, 1983:5).

Another case is that of "the government of the Cameroons which constructed a dam on the river Benue North of Garua and rendered useless all the efforts of the Benue River Development Authority" (Oshuntokun, op. cit: 179). Indeed, there was evidence that the military leadership in 1983 wanted to take out this dam but were stopped by the civilian leadership (Oshuntokun, ibid.) Had Nigeria a coherent Central African policy in a blueprint, where the essential core of Nigeria's interests are well enunciated; the pursuit of "good neighbourliness" strand of such policy would have been given a fillip.

Having examined the concept of Nigeria's African policy, one can now look more closely at the post-Apartheid era. On the surface, the concept strikes a cord inside one's mind - that which suggests that there had existed a Nigerian "African policy" in the Apartheid era. Truly, Nigeria's foreign policy was born in post-independence environment which imposed two policy imperatives, viz: "the need to exert Nigerian independence and thus maintain a modicum of credibility with the emergent African states, and secondly, the need to focus the national objective on an issue which would unite the support of all Nigerians and provide a distraction from the domestic rivalry in a singular national purpose and commitment" (Sinclair, op. cit: 5). It has been observed that the issues of Southern Africa in general and Apartheid in particular presented the country as well as other States on the continent, the opportunity to consolidate the concept of the national interest and self image (Sinclair, ibid: 46).

Furthermore, as reflected in most of the pronouncements of all Nigerian Heads of State, Presidents, or Prime Minister, the country "is committed to the cause of the total liberation of Africa and the abolition of racism in all its manifestations" (Gowon, 1975; Adebisi, 1977: 67-89; Shagari, 1980; Gambari, 1984). There is no debate on "the clarity and 


\section{Reshaping Nigeria's African Polity in a Post-Apartheid Era 37}

consistency that had for 30 years characterized Nigeria's policy on South Africa" (Dare, 1991: 15). Indeed, "so implacable has been Nigeria's opposition to Apartheid and so resolute its commitment to terminating it, that Nigeria has for about two decades been Chairman of the United Nations Special Committee Against Apartheid" (Dare, ibid). It was also reported that the federal government of Nigeria set up an anti-Apartheid committee whose function it was to promote public awareness of the evils of Apartheid (Adebisi, op. cit: 82). More important is the fact that "the one foreign policy issue around which all Nigerians unite" is the anti-Apartheid policy (Baker, 1984).

From the above, there is ample evidence that there was an Apartheid era, to which Nigeria responded. The next important question that deserves our attention is what constitutes the post-Apartheid era? Ordinarily, by the South African elections that took place from 26th to $29^{\text {th }}$ April, 1994, and the subsequent announcement of the results in which the National Party conceded defeat to the African National Congress, it could be said that a post-Apartheid era has been heralded.

In this study, post-Apartheid era connotes more than the above observation. Indeed, it is understood to mean any policy shift from the anti-Apartheid policy consensus which had hitherto dominated Nigeria's African, nay foreign policy, before the" South African elections. Thus, responding to many editorials and signed articles, which "had appeared in the news media urging the federal government to play its South African card in such a way that it can be assured of rich dividends from its moral and material investment in the anti-Apartheid struggle "(Dare, op. cit); an OTTOStment which have been put at" well over N68.05 billion" (Akintoye \& Afcor, 1994: a \& b) and secondly, being awakened to the reality that Hjgeria has neither permanent friends nor permanent enemies, but permanent interests (Garba, 1978:19); the Nigerian government started to prepare for post-Apartheid era in order to avoid the policy failures previously experienced with regards to her policy on the Southern African region as shown in the following examples.

In 1979, the Obasanjo government nationalized the assets of British Petroleum to influence British government's handling of Zimbabwean peace Talks and the eventual Zimbabwean independence in 1980 (Wright, 1985:5). Zimbabwe also became the beneficiary of a N10 million gift from Nigeria, a very timely gift which helped in the acquisition of the mete of Herald newspaper. Inspite of the negative as well as commercial consequences suffered by Nigeria on this action, "today, adverse reports cc Nigeria are a common feature in the Zimbabwean media, with the Braid ironically at the fore of the smear campaign" (Okwara, op. cit).

In 1976, Nigeria's influence was important to the O A. U's diplomatic backing of the MPLA government in Angola against South 
African-backed UNITA forces. It was reported that "years later, over fishing rights in Angola waters, the MPLA rejected Nigeria in favour of the former Soviet Union" (Okwara, ibid). Commenting on the Angolan MPLA government attitude over Nigeria's \$20 million cash gift to her, General Joe Garba, Nigeria's foreign affairs minister during the "support-MPLA" campaign, revealed that "at the first appearance of the MPLA government at the O AU. summit in Mauritius in July 1976, Nigeria's name was conspicuously absent from the list of countries to which they publicly paid tribute for assistance in achieving their independence" (Garba, 1987:23).

A third example comes from Namibia, the former South West Africa. This example is very recent since Namibia got her independence on 21 March 1990. It is on record that "in 1990, Nigerian policemen kept the peace in Namibia while elections went on, after three decades of diplomatic and financial support in the anti-Apartheid circuit" Furthermore, "Nigerians pooled together a N100 million contribution which was all handed over to the SWAPO-led government on Namibia's independence day" (Okwara, op. cit). It was reported that no mention was made in President Sam Nujoma's speech of Nigeria's role in his country's independence struggles.

Apparently, these countries which have benefited from Nigeria's support and financial aid have Africa as the centre-piece of their foreign policies, but have instead an African policy which consists of getting whatever foreign aid they can in Africa while remaining self respectful and inward looking as they develop their economies and political systems.

Indeed, the consequent hosting of President F. W. de Klerk and his wife at Abuja on 9th April 1992 marked the watershed in Nigeria's anti-Apartheid policy. One marked the end of anti-Apartheid policy, and the beginning of a post-Apartheid policy.

\section{III}

\section{CONSIDERATIONS FOR NIGERIA'S AFRICAN POLICY 1NAPOST-APARTHEID ERA}

Earlier in this paper, attempts have been made to examine the centrality of anti-Apartheid policy in Nigeria's African foreign policy. Similarly, what makes for an "Apartheid era" and "post-Apartheid era" periodization in Nigeria's foreign policy were also mentioned. In this section, attention is focused on the, considerations for Nigeria's African policy blueprint, which would be enduring and, at the same time, be amendable by successive Nigerian governments and people.

After 35 years of independence, the weight of history and prevailing circumstances of the international system on the formulation as well as 
the execution of Nigeria's foreign policy in which Africa is given an important part are very real and still remain relevant. Two aspects of these factors worth considering in this discussion are: first, the dependence deriving from Nigeria's colonial past. Second is the change from the cold war to post-cold war international outlook.

If the cold war made Nigeria's search for an international role to be reduced to championing the interests of the African man and those of African descent, the evolving post-cold war international system imposes the necessity on Nigeria to become more coordinated internally, viz: politically, economically and scientifically, so as to portray a beacon of hope to the African man and those of African descent. With such a sound domestic base, Nigeria can pursue a credible African policy, formulated exclusively for realizing the chosen goal of respect for the people of the race, of which she aspires to be their spokes nation.

It follows that although, Nigeria's African policy in the post-Apartheid era has to divest itself from the rigid anti-Apartheid ideology, it, nevertheless, remains imperative that Nigeria's global responsibility to the African man and people of African descent be imputed into the philosophy of the envisaged post-Apartheid policy on Africa. There is still enough justification for this. In fact, the demands for reparations made on the colonial warlords of Europe by the O.A.U. should be internalized by Nigeria's future democratically elected government.

One cannot but agree with the notion that "world politics has always been the politics of group interests and the larger and more geographically diffuse the group, the more essential it has been for it to discover a voice and a spokesman that can be relied upon not to betray the group's aspirations (Cole, 1979:2). Pursuing this further, it has been observed that what the Germans call weltpolitik, meaning that race or the pigmentation of one's skin is the greatest determinant of world politics is neatly summarized thus: "the greatest fact of the 20th century is race" (Oshuntokun, 1987:171).

It is in the light of the above that Nigeria's policy in the post-Apartheid era could be more relevant if it has as its core philosophy, the articulation of Nigeria's interest defined as building up of an internally strong domestic economy, observance of fundamental human rights, coupled with a viable political culture and system which can then be held up as a shining example to and for influencing as well as defending the African countries and people of African descent

The above core philosophy could then be strategically defined along what MajorGeneral Muhammadu Buhari and his foreign affairs minister, Professor Ibrahim Gambari developed viz: the concept of four concentric circles of foreign policy. The first one is Nigeria's immediate security interests and policies with neighbours; the second one which 
covers the west African region and the Economic Community of West African States (ECOWAS); the third which concerns the whole Africa and the fourth covers relations with countries outside of the continent (Wright, 1985:7).

In essence, the argument in this paper is that "Africa of course would always remain the focus of our foreign policy but the strategy being pursued is the wrong one" (Oshuntokun, op. cit). A little modification can still be made to the concentric circles discussed above, the modification lies in having a blueprint for each of the circles; say, for example, on Nigeria's relations with the immediate four surrounding countries; with ECOWAS as both an organization and individual member countries of the region, otherwise known as a West African policy blueprint. The critical issue to be addressed by these policy blueprints lies on Nigeria's security, both of their borders and her citizens transacting trade and commerce in those countries and vice versa. On the third circle, there should be a Nigerian policy on Eastern and Southern Africa separate from the policy on O.A.U as an organization. Such policy should contain the crucial issue of Nigeria's search for "friends who will be militantly behind us" in the world politics of defending our sought-after role of spokesperson for the African race and those of African descent.

Besides the making of regional policies coming out of the enunciated concentric circles as the main focus of Nigeria's African policy in the post-Apartheid era, the reshaping that we may look forward to has been taken care of with the modifications of the relevant constitutional provisions regarding the place of Africa and African affairs. Section 19 of the 1979 Constitution of the Federal Republic of Nigeria, lists the following as what Nigerian policy objectives should be:

The State shall promote African Unity, as well as total political, economic, social and cultural liberation of Africa and all other forms of international cooperation conducive to the consolidation of universal peace and mutual respect and friendship among all peoples and States and shall combat racial discrimination in all its manifestations (FGN, 1980:10).

The corresponding section 20, chapter 11 of the 1989 Constitution of the Federal Republic of Nigeria further articulates Nigeria's commitment to the:

Promotion of the total liberation of Africa and support of African unity, promotion of universal peace and mutual respect among all nations and elimination of racial discrimination in all its manifestations (TPL, 1989:30). 
A closer look at the two provisions brings vividly to us what are likely to be the emphasis, the style and the form of "Africa as the centre-piece of our foreign policy" in post-Apartheid era. Noticeable in the different constitutional provisions is the fact that in the Apartheid era, Nigeria's African policy employed and indeed tried to "combat" racial discrimination. It is possible that Nigeria's African policy in the post-Apartheid era will probably witness a linkage between the need for the "elimination" of racial discrimination and mutual respect among all nations. This, thus, leads us to the importance of the "nuances of style" (Nnoli, 1976:30) of the in-coming President, National Assembly members as well as the political class as a whole.

The belief system of Nigerian leaders would no doubt affect the implementation or the reshaping of Nigeria's African policy in the post-Apartheid era. The observed tendency of Nigerian leaders to view the plight of Africans in Southern Africa in noneconomic and moral terms Nnoli, ibid), has to evolve into a coherent demand for reciprocity in Nigerian foreign policy (Akinyemi, 1987: 151-56) founded on sound economic diplomacy (Adelusi, 1991: 16-20). Pushing the argument further, it has been observed that the bourgeois nature of the Nigerian military and civilian regimes predisposes them to an acceptance of the definition of politics as concerning the ultimate allocation (distribution) of resources in a society. It prevents them from being predominantly oriented towards production. They tend-to treat the economic structure of the society as if it is an indifferent condition of socio-political action (Nnoli, op. cit). A change in or gradual movement from this kind of belief system could advance Nigeria's policy in post-Apartheid era. As a first step in the way of injecting the economic variable, a proposal on the multinationalization within Africa of indige-nous Nigerian businesses as an option towards the policy goals could be examined in conjunction with the "economic diplomacy" being pursued at present.

On the issue of reciprocity in Nigerian foreign policy, Professor A B. Akinyemi dwelt greatly on this as a principle which seeks to confront Nigeria's response to crisis in international affairs. The argument underlying this principle is explicitly stated thus: "if when we say that Africa is the centre-piece of our foreign policy, we mean that Nigeria identifies with and defends the legitimate interests of Africa, collectively, then it also means that Africa and African States should identify with and defend Nigeria's interests" (Akinyemi, op. cit 154). A credible Nigerian African policy in poet-Apartheid era could be informed by this reciprocity principle, which is "a necessary attribute of sovereignty" (Akinyemi, ibid). In fact, the observed situation in which the "...years of economic crisis in Nigeria have yet to elicit - supportive response from the few African States which are in a position to do so, such as in the areas of smuggling and currency trafficking" (Akinyerni, ibid: 154), should not be allowed to continue or repeat itself. 


\section{IV}

\section{CONCLUSION}

In this paper, attempts were made to establish the major difference between Nigeria's Africa-is-the-centre-piece-of-our-foreign-policy posturing and the desired Nigerian "African policy". The strategies and policies adopted to prosecute the initiative under the Apartheid era were considered inadaptable in many respects, to the envisaged Nigerian African policy in the post-Apartheid era. In many respects, the anticipated influence of the evolving democratic pluralism in the form of civilian-controlled political system as well as the new international order of the post-cold war era were highlighted as important variables to watch in reshaping Nigeria's African policy in the post-Apartheid era.

The necessary change in the belief system of Nigerian leaders form the usual moralistic to rational economic-consideration were found indispensable to Nigeria's relations with post-Apartheid South Africa. A multi -racial and democratic South Africa, inspite of its abundant natural resources (if left uncarted away by the Anglo-American conglomerates) and industrial growth, will certainly continue grappling with many national questions for sometime to come.

In conclusion, Nigeria must, in her post-Apartheid policy, formulate coherent regional policy blueprints for each homogeneous geographical region such as West Africa, Maghrebin Region, Horn of Africa, Central Africa, East and. Southern Africa, as well as for regional organizations such as ECOWAS, O AU. and the African Economic Community. Nigeria could also look into a reexamination and possible adoption of both the principle of reciprocity and economic diplomacy, the formulation of strategies for the upliftment of the dignity of the African man and people of African descent under a conducive environment where guarantees of fundamental human rights go along with economic development.

It is the above option that can really contribute towards making Nigeria and, indeed, Africa relevant (Da Costa, 1992) in world affairs long after the dawn of the postApartheid era.

\section{NOTES AND REFERENCES}

Jaja Wachuku (1983): in United Nations General Assembly Official Records, 16th

Session, 1031st Plenary Session, October 10, 1961, p. 339 as cited in Michael Sinclair, "An Analysis of Nigerian Foreign Policy: The Evolution of Political Paranomia." Occasional Paper. Braamfoutein: The South African Institute of International Affairs. 
Reshaping Nigeria's African Policy in a Post-Apartheid Era 43

Oye Ogunbadejo (1977): "General Gowon's African Policy" International Study® Vol. 16, No. 1. January/March, pp. 36-50.

T. A Imobighe, Introduction to "The Long Road to Nigeria's Africa-Centred Foreign Policy" In Nigeria's African. Policy in the Eighties. Kuru: NIPSS p. 13.

See, A March of Progress:: Collected Speeches of His Excellency: Lieutenant General Olusegun Obasanjo. Lagos: Federal Ministry of Information, p. 49,

Stephen Wright, in West Africa (London): 27 July 1981, p. 1685.

O. Fafowora, "Nigeria in the African Setting." In Nigeria's Policy in the Eighties. Kuru: NIPPS, op. cit. p. 32.

Daniel Bach (1985): "Le Nigeria en Afrique de l'Quest: Limites et Paradoxes d'une Influence" Table Ronde. Bordeauz, France: C.E AN, 2-3 May, p. 7.

Jide Oshuntokun (1987): "The Thrust of Nigeria's Foreign Policy in the Future." In Nigerian Forum (Lagos: N.I.I.A), Vol. 7 NX 5 \& 6. May/June, p. 178.

Joseph Garba (1978): "Impact of Our Foreign Policy on National Objectives." (Kaduna) New Nigerian, February 17,1978. p. 13.

Michael Sinclair "An Analysis of Nigerian Foreign Policy: The Evolution of Political Paranoia." Occasional Paper. Braamfoutein: The South African Institute of International Affairs. 1983. p. 5.

See President Shehu Shagari, Presidential Address te the Nigerian National Assembly, House of Representatives Debates. Vol. 4, NX 40, March 28,1980. Col. 2074 as cited by M. Sinclair, op. eit. p. 9 .

General Gowon was also quoted as expressing similar views. See "Message of Goodwill from The Federal Military Government of Nigeria to the Government of the People's Republic of Angola." December 19,1975.

Busari Adebisi (1977): "Nigeria's Relations with South Africa (1960-1975)" Africa Quarterly 16(3), pp. 67-89.

See Ibrahim Gambari in West Africa (London): 22 October, 1984,

Olatunji Dare, "Nigeria and South Africa" The Guardian (Lagos), 30 July 1991. p. 15.

Pauline H. Baker (1984): "A Giant Staggers: Nigeria as an Emerging Regional Power" In Bruce E. Arlinghaus, African Security Issues: Sovereignty, Stability and Solidarity Boulder, Colorado: West-view press, p. 86. 
44 Annals of The Social Science Council of Nigeria, No. 6, January-December 1994

Haroun Adamu (1992): "Balance of Power and its Consequences on the New World Order." The Democrat (Kaduna), March 11, p. 3.

Jonas Okwara (1992): "De Klerks'Visit: Gain or Vain Diplomacy?" The Guardian On Sunday (Lagos). 12 April p. A5.

Stephen Wright (1985), "Nigeria and South Africa 1975-85: Economic, Political and Strategic Considerations" TableRonde (Bordeaux), 2-3 May, p. 5.

Joe Garba (1987): Diplomatic Soldering: Nigerian Foreign Policy, (1975 -1979) Ibadan: Spectrum Books, p. 23.

Dele P. Cole (1979): "Black Solidarity and World Politics" Daily Times (Lagos), August 16, p. 2.

Jide Oshuntokun (1987): "The Thrust of Nigeria's Foreign Policy in the Future" Nigerian Forum (Lagos), Vol. 7 NX 5 \& 6. May/June, p. 171.

.Federal Government Printer (Lagos) 1979 Constitution of the Federal Republic of Nigeria, Reprinted in 1980, p. 10.

Times Press Limited, (Apapa): 1989 Constitution of the Federal Republic of Nigeria, p. 30.

Okwudiba Nnoli (1976): "Nigerian Policy towards Southern Africa" Nigerian Journal of International Affairs (Lagos: N.I.LA), Vol. 2. No. 1\& 2, p. 30.

A B. Akinyemi (1987): "Reciprocity in Nigerian Foreign Policy" Nigerian Forum Lagos: (N.I.I.A), Vol. 7, NX 5 \& 6 May/June p. 151-156.

Olufemi Adelusi (1991): "Nigeria's Relations with France and The Concept of Economic Diplomacy" Nigerian Forum (Lagos: N.I.I.AX Vol. 11, No. 1 \& 2, January/February, pp, 16-20.

Gilbert Da Costa (1992): "Nigeria, U.N. and the South African Question" West Africa (London), 13-19 July.

S. Akintoye \& A Akor (1994a \& b): "Nigeria Committed N6 Billion to Fighting Apartheid" In The Guardian On Sunday (Lagos), 24 April. 